\title{
Хірургічне лікування хворих на гостру товстокишкову непрохідність
}

\author{
I. M. SHEVCHUK, O. V. NOVYTSKYI, M. H. SHEVCHUK, A. L. SHAPOVAL \\ SHEI "Ivano-Frankivsk National Medical University"
}

\section{SURGICAL TREATMENT OF PATIENTS WITH AN ACUTE COLORECTAL OBSTRUCTION}

\begin{abstract}
Проведено аналіз результатів лікування 85 хворих із гострою товстокишковою непрохідністю пухлинної і непухлинної етіології, які перебували на лікуванні впродовж 2007-2014 рр. Серед них 48 (56,5 \%) чоловіків, 37 (43,5 \%) жінок, віком від 22 до 88 років, у віці 60 і більше років - 52 (61,2 \%) хворих. У 54 (63,5 \%) пацієнтів діагностовано обтураційну гостру товстокишкову непрохідність на грунті колоректального раку. При декомпенсованій гострій товстокишковій непрохідності колоректальний рак діагностовано у 72,4 \% пацієнтів. Для ліквідації декомпенсованої кишкової непрохідності застосовували накладання розвантажувальної колостоми на різному рівні - у 58,6 \%, обхідних міжкишкових анастомозів - у 24,1 \%, правобічну геміколектомію - у 13,8 \% хворих. Етапні хірургічні втручання виконано у 55,1 \% із 29 хворих 3 декомпенсованою непрохідністю. У 56 (65,9 \%) з 85 пацієнтів консервативними заходами вдалося ліквідувати гостру кишкову непрохідність і провести радикальне операційне втручання у плановому порядку. В ранньому післяопераційному періоді померли 3 (3,5 \%) хворих.
\end{abstract}

There were analyzed results of treatment of 85 patients with an acute colorectal obstruction neoplastic and non-neoplastic etiology, who passed treatment in period of 2007-2014. Among them 48 (56.5\%) patients were men, 37 (43.5 \%) patients were women, 52 $(61.2 \%)$ patients were older 60 years. 54 patients $(63.5 \%)$ had obstructive colorectal obstruction because of colorectal cancer. With signs of decompensated colorectal obstruction there were $34.1 \%$ of patients, among them $72.4 \%$ of patients as a backstage had cancer of colon. For elimination of decompensated colorectal obstruction were used discharged stoma in $58.6 \%$ patients, round about anastomoses between intestines in $24.1 \%$ patients, right-sided hemicolectomy - in $13.8 \%$ of patients. Phase radical surgical operations were performed for $55.1 \%$ of patients with decompensated colorectal obstruction. 56 (65.9\%) patients passed effective concervative treatment for colorectal obstruction elimination with disappearing of acute colorectal obstruction signs and performing of one-stage surgical operation in planned order. After surgical operations 3 (3.5\%) patients died.

Постановка проблеми і аналіз останніх досліджень та публікацій. В останнє десятиріччя відзначають зростання числа колопроктологічних захворювань та їх ускладнених форм [1]. Гостра товстокишкова непрохідність (ГТН) залишається одним із найбільш частих ускладнень, питома вага якого коливається в широких межах - від 12,2 до $86 \%$ [2].

Найчастішою причиною ГТН є злоякісні пухлини товстої кишки [3]. Середпричин колоректальних захворювань злоякісні новоутворення займають четверте місце [4]. За даними більшості авторів, частота обтураційної ГТН при колоректальному раку становить від 30 до 77 \% [1, 3, 4]. Число хворих на рак даної локалізації неухильно зростає, а пацієнти, старші 60 років, складають 80-90 \% [5]. За медичною допомогою 60-90 \% хворих на обтураційну ГТН при колоректальному раку звертаються у строки три і більше діб, що визначає високі показники летальності, яка становить 23-52 \% [6].
Незважаючи на постійне вдосконалення методів діагностики, питання своєчасного виявлення та вибору раціональної хірургічної тактики у хворих на ГТН непухлинної етіології також залишаються остаточно невирішеними, про що свідчать високі показники післяопераційних ускладнень, які сягають 38,6-80 \%, і летальності - на рівHi 25,1-46,1 \% [1, 4, 5].

Мета роботи: проаналізувати особливості xiрургічного лікування хворих на гостру товстокишкову непрохідність пухлинної і непухлинної етіології та оцінити його результати.

Матеріали і методи. Проведено аналіз результатів лікування 85 хворих із гострою товстокишковою непрохідністю пухлинної і непухлинної етіології, які перебували на лікуванні в проктологічному відділенні Івано-Франківської обласної клінічної лікарні впродовж 2007-2014 рр. Серед них 48 (56,5\%) чоловіків, 37 (43,5\%) жінок, віком 
від 22 до 88 років, з них у віці 60 і більше років $52(61,2 \%)$ хворих.

У 54 (63,5 \%) пацієнтів діагностовано обтураційну ГТН на ґрунті колоректального раку. В правій половині ободової кишки пухлину діагностовано в 11 (20,4 \%), в лівій половині - у 23 (42,6 \%) хворих (табл. 1).

У 31 (36,5 \%) хворого ГТН виникла при непухлинних захворюваннях товстої кишки. ГТН на рівні правої половини ободової кишки діагностовано у 9 (20 \%) хворих, поперечноободової кишки - у 8 (25,8 \%), лівої половини ободової кишки у 14 (45,2 \%), ректосигмоподібного відділу ободової кишки - в одного хворого (табл. 2).

Серед обстежених 85 хворих перфорацію стінки товстої кишки в ділянці пухлини діагностували у 6 (7,1 \%), параколічний абсцес при хворобі Крона - у 3 (3,5 \%), діастатичні розриви при неспецифічному виразковому коліті в одного, а також анемію тяжкого ступеня (гемоглобін нижче 60 г/л) - у 26 (30,6 \%) пацієнтів.

У 57 (67,1\%) хворих діагностовано різноманітні супутні захворювання, переважно серцевосудинної, ендокринної, сечовидільної системи та органів дихання. Серед супутніх захворювань явища поліморбідності мали 12 (21,1 \%) хворих (системні прояви атеросклерозу, ішемічна хвороба серця, перенесений інфаркт міокарда, ате-

Таблиця 1. Локалізація колоректального раку

\begin{tabular}{||l|c|c||}
\hline \multirow{2}{*}{\multicolumn{1}{|c|}{ Рівень локалізації }} & \multicolumn{2}{|c|}{ Число випадків } \\
\cline { 2 - 3 } & $\mathrm{N}$ & (\%) \\
\hline Ректосигмоподібний відділ & 15 & 27,8 \\
\hline Селезінковий згин & 9 & 16,7 \\
\hline Сигмоподібна кишка & 8 & 14,8 \\
\hline Низхідний відділ & 6 & 11,1 \\
\hline Поперечноободова кишка & 5 & 9,3 \\
\hline Висхідний відділ & 4 & 7,4 \\
\hline Печінковий згин & 4 & 7,4 \\
\hline Сліпа кишка & 3 & 5,5 \\
\hline \hline
\end{tabular}

Таблиця 2. Причини гострої товстокишкової непрохідності при непухлинних захворюваннях

\begin{tabular}{||l|c|c||}
\hline \multirow{2}{*}{\multicolumn{1}{|c|}{ Характер захворювань }} & \multicolumn{2}{|c|}{ Число випадків } \\
\cline { 2 - 3 } & $\mathrm{N}$ & $\mathbf{( \% )}$ \\
\hline Дивертикулярна хвороба & 13 & 41,9 \\
\hline Хвороба Крона & 5 & 16,1 \\
\hline Поліпоз товстої кишки & 4 & 12,9 \\
\hline Мегаколон & 4 & 12,9 \\
\hline Неспецифічний виразковий коліт & 3 & 9,7 \\
\hline Хвороба Гіршпрунга & 2 & 6,5 \\
\hline \hline
\end{tabular}

росклеротичне ураження судин нижніх кінцівок, доброякісна гіперплазія передміхурової залози та ін.). Коморбідність встановлено в 17 (29,8 \%) пацієнтів. По одному супутньому захворюванню мали 28 (49,1 \%) обстежених хворих.

Діагностику ГТН пухлинної і непухлинної етіології здійснювали на підставі даних об'єктивного i лабораторного обстеження, пальцевого обстеження прямої кишки, аналізу результатів оглядової рентгенографії органів черевної порожнини, іригоскопії (-графії), ректороманоскопії, колоноскопії та ультразвукового дослідження. Ступінь порушення кишкової прохідності визначали за класифікацією Э. Г. Топузова (1989) [7].

Результати досліджень та їх обговорення. Відповідно до класифікації Э. Г. Топузова (1989), серед 85 обстежених хворих компенсований ступінь порушення кишкової прохідності встановлено у $6(7,1 \%)$ пацієнтів, субкомпенсований - у 50 (58,8 \%), декомпенсований - у 29 (34,1 \%) хворих.

Клінічна симптоматика ГТН відрізнялася залежно від локалізації захворювання у відділах ободової кишки. Незалежно від етіології ГТН, при локалізації патологічного процесу в правій половині ободової кишки для 20 (23,5 \%) із 85 хворих найбільш постійними клінічними ознаками захворювання були втрата маси тіла у 16 (80\%), вторинна анемія (гемоглобін нижче 60 г/л) - у 17 (85\%), метеоризм - у 15 (75 \%), порушення випорожнень у 12 (60 \%), натомість патологічні виділення з калом спостерігали лише у 3 (15 \%) пацієнтів.

При ГТН на рівні поперечноободової кишки для $12(14,1 \%)$ із 85 хворих найбільш характерними були метеоризм - у 11 (91,7 \%), переймоподібний біль - у 10 (83,3 \%), порушення випорожнень - у 8 (66,7 \%), втрата маси тіла - у 6 (50 \%) та вторинна анемія - у 5 (41,7 \%) хворих.

При ГТН лівої половини ободової кишки серед 37 (43,5 \%) із 85 хворих порушення випорожнень реєстрували у 34 (91,9 \%) пацієнтів, біль - у 31 (83,7 \%), метеоризм - у 18 (48,6 \%), патологічні виділення з калом - у 17 (45,9 \%) хворих, втрату маси тіла та вторинну анемію відзначено в 11 (29,7 \%) пацієнтів.

При ГТН на рівні ректосигмоподібного відділу та прямої кишки серед 16 (18,9 \%) хворих переважали патологічні виділення з калом - у 14 (87,5 \%), порушення випорожнень - у 12 (75 \%). Втрату маси тіла та вторинну анемію відзначено у 9 (56,3 \%) хворих.

Об'єм операції залежав від причини ГТН, локалізації патологічного процесу, ступеня порушення кишкової прохідності, ефективності лікві- 
дації ГТН консервативними заходами, тяжкості загального стану хворого, віку і характеру супутніх захворювань.

Серед 85 обстежених на ГТН 29 (34,1 \%) хворих були госпіталізовані в ургентному порядку, переважно на 3-5-ту добу від початку захворювання. У зв'язку з неефективністю консервативних заходів ліквідації декомпенсованої ГТН операційне втручання у цих хворих проводили після короткочасної передопераційної підготовки і консультацій суміжних спеціалістів у перші 6 год з часу госпіталізації. Причинами декомпенсованої ГТН серед 29 хворих були колоректальний рак у 21 (72,4 \%) пацієнта, хвороба Крона - у 3 (10,3 \%), дивертикулярна хвороба товстої кишки у 2 (6,9\%), хвороба Гіршпрунга - у 2 (6,9 \%), мегаколон - в одного хворого.

Для ліквідації декомпенсованої ГТН застосували накладання розвантажувальної колостоми на різному рівні у 17 (58,6 \%) пацієнтів, обхідних міжкишкових анастомозів - у 7 (24,1 \%), правобічну геміколектомію - у 4 (13,8 \%), операцію Гартмана - в одного хворого. При пухлинах правої половини товстої і сліпої кишки виконували правобічну геміколектомію. За наявності поодиноких метастазів у печінці їх видаляли. При множинному ураженні печінки метастазами накладали ілеотрансверзоанастомоз. Хворим з локалізацією декомпенсованої ГТН на грунті раку в ділянці ректосигмоподібного кута або дистального відділу сигмоподібної кишки, з огляду на можливість проведення в подальшому радикальної операції, перевагу віддавали формуванню трансверзостоми. У 3 (10,3 \%) пацієнтів при розповсюдженні пухлинного процесу на інші органи черевної порожнини додатково виконали резекцію петлі тонкої кишки (2 хворих), спленектомію (1 хворий).

Етапні хірургічні втручання виконано у 16 $(55,1 \%)$ із 29 хворих. На першому етапі формували розвантажувальну колостому для ліквідації декомпенсованої ГТН, на другому етапі, не раніше ніж через місяць за відсутності ускладнень, проводили радикальні втручання на товстій кишці 3 формуванням первинного товстокишкового анастомозу. Закриття розвантажувальної колостоми виконували за відсутності ознак рецидиву пухлинного росту через 3-6 міс.

У 56 (65,9 \%) 385 хворих консервативними заходами вдалося ліквідувати ГТН і провести радикальне операційне втручання у плановому порядку. Серед радикальних операційних втручань правобічну геміколектомію виконано у 14 (25 \%) пацієнтів, лівобічну геміколектомію - у 19 (33,9 \%), резекцію поперечної ободової кишки - у 7 (12,5 \%), резекцію сигмоподібної кишки - у 7 (12,5 \%), резекцію ректосигмоподібного відділу в 6 (10,7 \%), колектомію - у 3 хворих.

При гістологічному дослідженні у прооперованих пацієнтів із пухлиною ободової кишки найбільш часто верифікували аденокарциному різного ступеня диференціації (83,4 \% спостережень).

Ускладнення виникли в 11 (12,9 \%) хворих. Аналізуючи ускладнення, ми встановили вплив характеру товстокишкової непрохідності і методу застосованого операційного втручання на частоту їх виникнення. При декомпенсованій ГТН ускладнення виникли у 9 (31 \%) із 29 хворих, в т. ч. нагноєння лапаротомної рани - у 5 (17,2 \%), неповна евентрація - у 3 (10,3 \%), парастомічна флегмона - в одного хворого. Серед 56 (65,9 \%) пацієнтів, прооперованих у плановому порядку з причини компенсованої ГТН, ускладнення мали тільки 2 (3,6 \%) хворих у вигляді нагноєння післяопераційної рани.

У ранньому післяопераційному періоді померли 3 (3,5 \%) пацієнтів. 3 них при раку сигмоподібної кишки, ускладненому декомпенсованою ГТН з перфорацією стінки кишки і поширеним каловим перитонітом (2 хворих), при раку селезінкового згину ободової кишки, ускладненому декомпенсованою ГТН (один хворий).

Висновки. 1. Гостра товстокишкова непрохідність пухлинної і непухлинної етіології залишається одним із найбільш частих ускладнень в колопроктології. У 63,5 \% хворих діагностовано обтураційну товстокишкову непрохідність на грунті колоректального раку. Кожний третій хворий був госпіталізований у пізні строки розвитку цього ускладнення з явищами декомпенсованої товстокишкової непрохідності, з них на грунті раку товстої кишки - 72,4 \% пацієнтів. Для ліквідації декомпенсованої товстокишкової непрохідності застосували накладання розвантажувальної колостоми у 58,6 \% хворих, обхідних міжкишкових анастомозів - у 24,1 \% пацієнтів, правобічну геміколектомію - у 13,8 \% осіб. Етапні радикальні хірургічні втручання виконано у 55,1 \% хворих із декомпенсованою товстокишковою непрохідністю. Померли 3 (3,5 \%) із 85 обстежених пацієнтів.

2. Наведені факти свідчать про актуальність питань ранньої діагностики захворювань товстої кишки на догоспітальному рівні надання медичної допомоги. Разом з тим, сучасні можливості хірургії та інтенсивної терапії дозволяють розширити показання до радикальних операцій при товстокишковій непрохідності, незважаючи на поширеність процесу, зменшити післяопераційну летальність і поліпшити якість життя хворих. 


\section{З ДОСВІДУ РОБОТИ}

\section{СПИСОК ЛІТЕРАТУРИ}

1. Алиев С. А. Современные тенденции и перспективы в хирургическом лечении опухолевой непроходимости ободочной кишки у больных старших возрастных групп / С. А. Алиев // Рос. онкологический журнал. - 2005. - № 4. - С. 21-29.

2. Хирургическое лечение обтурационной непроходимости ободочной кишки / В. 3. Тотиков, А. К. Хестанов, К. Э. Зураев [и др.] // Хирургия. - 2001. - № 8. - С. 51-54.

3. Сидоренко Ю. С. К вопросу о тактике лечения больных с осложненными формами рака толстой кишки на современном этапе / Ю. С. Сидоренко, С. А. Грушко, В. П. Назаренко // Проблемы колопроктологии : сб. тр. - Вып. 18. - М., 2002. С. 432-438.

4. Соловейчик А. С. Острая кишечная непроходимость при раке толстой кишки / А. С. Соловейчик, Н. Н. Свистунов, А. В. Пирогов // Материалы международного конгресса хирургов. - Петрозаводск, 2002. - Т. 2. - С. 112-113.

5. Хирургическая тактика при восстановительных операциях на толстой кишке / М. П. Захараш, А. И. Пойда, В. М. Мельник [и др.] // Хирургия. - 2006. - № 7. - С. 51-55.

6. Опыт хирургического лечения диастатических разрывов ободочной кишки / А. А. Курыгин, С. И. Перегудов, Г. И. Синенченко, А. В. Пирогов // Вестник хирургии им. И. И. Грекова. - 2008. - № 3. - С. 49-53.

7. Топузов Э. Г. Диагностика и лечение острой кишечной непроходимости при раке толстой кишки / Э. Г. Топузов // Вестник хирургии им. И. И. Грекова. - 1989. - № 12. - С. 76-78.

Отримано 26.08.15 